\section{In Vitro Shoot Proliferation and Root Induction of Shoot Tip Explants from Mature Male Plants of Casuarina cunninghamiana Miq.}

\author{
Xiuli Shen ${ }^{1}$, William S. Castle, and Frederick G. Gmitter, Jr. \\ Citrus Research and Education Center (CREC), Institute of Food and \\ Agricultural Sciences (IFAS), University of Florida (UF), 700 Experiment \\ Station Road, Lake Alfred, FL 33850-2299
}

Additional index words. IBA, explant type, explant orientation, in vitro rooting, River sheoak, shoot multiplication, TDZ, tissue culture

\begin{abstract}
This study examined the effects of plant growth regulators, explant types, and their orientations on in vitro shoot proliferation of Casuarina cunninghamiana Miq. and also the subsequent rooting ability of shoots. Results showed that shoot proliferation occurred only in shoot tip explants cultured vertically on Murashige and Skoog (MS) medium supplemented with 2 or $4 \mu M$ thidiazuron (TDZ). Neither 6-benzylaminopurine alone nor in a combination with 1-naphthalene acetic acid (NAA) or gibberellic acid had any effect on shoot proliferation. TDZ at $4 \mu \mathrm{M}$ resulted in the greatest percentage of axillary bud sprouting (70\%) and mean number of sprouts per explant (2.3). Additionally, no shoot proliferation was observed from detipped or single-node explants or from horizontally placed shoot tip explants when cultured on the same TDZ-containing medium. The induced shoots produced adventitious roots on MS medium supplemented with 2.5, 5, or $10 \mu \mathrm{M}$ indole-3-butyric acid (IBA), not with indole-3-acetic acid and NAA. Although the mean number of roots per explant was not significantly different between 2.5 and $5 \mu M$ IBA, the highest rooting percentage $(68 \%)$ and mean length of roots per explant $(0.7 \mathrm{~cm})$ was achieved at $5 \mu \mathrm{M}$ IBA. The current study provided preliminary information toward commercial in vitro propagation of Casuarina cunninghamiana male plants.
\end{abstract}

Casuarina cunninghamiana Miq., a large, woody forest tree of the family Casuarinaceae, has many uses related to its rapid growth, large size, good branching, and survival when planted in impoverished environments less suited for many other trees. It also is an important plant for agroforestry because of its good timber and use as firewood (Midgley et al., 1983). In Florida, Casuarina has been present for approximately a century but recently became regulated because of concern about invasiveness (Castle, 2008). However, for the reasons mentioned, there is now interest in using these plants as a windbreak for citrus groves to help manage citrus canker disease, a windblown bacterial infection caused by Xanthomonas axonopodis pv. citri. A recent change in its legal status allows $C$. cunninghamiana male plants to be propagated from local sources only for restricted use as windbreaks (Castle et al., 2008).

Conventional propagation methods have been problematic for C. cunninghamiana, especially in large-scale commercial operations. Seed germination rates of this species are often extremely low (less than 50\%), and

Received for publication 12 Feb. 2010. Accepted for publication 16 Mar. 2010.

${ }^{1}$ To whom reprint requests should be addressed; e-mail xis300@ufl.edu. seedlings exhibit undesirable variability in growth and form (El-Lakany and Shepherd, 1983; Shen et al., 2009a). In preliminary experiments, we found that seeds from local sources did not germinate whether the seeds were harvested from recently matured or older cones (unpublished data). Elsewhere in the world, where $C$. cunninghamiana is grown commercially for citrus windbreaks, seeds are the preferred propagation method and germination rates are apparently not a problem.

Low success rates were also reported when propagation was attempted by rooting cuttings and air layering (Lundquist and Torrey, 1984). We also experienced problems of poor rooting of cuttings and little axillary bud proliferation in propagation trials with male plants of C. cunninghamiana (unpublished data). Root suckers are another means of vegetative propagation for some Casuarina species (Husain and Ponnuswamy, 1980). However, C. cunninghamiana trees in Florida do not produce suckers. The trees are dioecious, so seeds are not an option for propagation of male trees as required in Florida. Seed populations are mixed and the limited literature on the subject suggests that it requires $\approx 4$ to 7 years for the plants to flower and reveal their gender (Castle et al., 2008). In vitro procedures offer a promising means of propagation for species that are difficult to propagate by conventional methods. Research on in vitro propagation of Casuarina is limited, but experiments have been conducted on some species, including the related Allocasuarina verticillata Lam (Phelep et al., 1991), C. equisetifolia (Duhoux et al., 1986; Seth et al., 2007), C. glauca, and C. cunninghamiana (Aboel-Nil, 1987). In most of studies, seedlings or young immature trees were used as explant sources. There have been no reports on successful in vitro propagation of $C$. cunninghamiana using tissues from mature male trees. We have established a protocol for micropropagation of a Casuarina hybrid $(C$. equisetifolia L. $\times C$. glauca Sieber ex Spreng) using epicotyl explants excised from seeds germinated in vitro. Shoot proliferation was obtained on Murashige and Skoog (MS) medium (Murashige and Skoog, 1962) supplemented with 6-benzylaminopurine (BA) at 0 to $35.6 \mu \mathrm{M}$ and root induction on MS medium supplemented with indole-3butyric acid (IBA) from 4.3 to $17.4 \mu \mathrm{M}$ (Shen et al., 2009b). However, this in vitro protocol was not successful using shoot tips taken from mature male $C$. cunninghamiana trees in our preliminary experiment. Therefore, our objectives were: 1) to investigate the effects of plant growth regulators (PGRs) (type, concentration, and combination), explant type (entire shoot tip, detipped, and single node), and explant orientation (vertical and horizontal) on shoot proliferation; and 2) to examine the effects of three types of auxin [indole-3-acetic acid (IAA), IBA, and 1-naphthalene acetic acid (NAA)] on in vitro rooting of $C$. cunninghamiana shoots.

\section{Materials and Methods}

Plant materials. Plant materials were collected from three naturalized mature male trees of $C$. cunninghamiana estimated to be more than 40 years of age located in Fort Pierce, FL (lat. 27.4487, long. 80.3759). The male nature of the source trees was determined by examining flower type. Lower branches of the source trees were pruned in Dec. 2008 to produce new growth. When newly formed branches were $\approx 3$ months old and 2 to $8 \mathrm{~cm}$ long, tip cuttings were taken (Fig. 1A), placed in plastic bags with water, and kept in a cooler over ice. Explants were placed on culture medium within $24 \mathrm{~h}$ of sample collection.

Sterilization procedure. In preliminary experiments, we experienced high contamination rates when initiating cultures. The following sterilization procedure worked best for reducing contamination rate and increasing explant survival. Shoot tips (2 to $3 \mathrm{~cm}$ ) long, with no visible axillary buds, were taken from cuttings and placed under running water for $30 \mathrm{~min}$ followed by 20 -min soaking in $20 \% \mathrm{v} / \mathrm{v}$ regular bleach $(1.2 \%$ sodium hypochlorite) with the addition of 2 drops of Tween-20 and then rinsed three times, $5 \mathrm{~min}$ each, with sterile water. The basal end of shoot tips was trimmed to remove bleachdamaged tissue. Shoot tips $\approx 1.5 \mathrm{~cm}$ long (Fig. 1B) were used as initial explants for in vitro culture.

General culture media and conditions. Culture medium consisted of MS mineral 


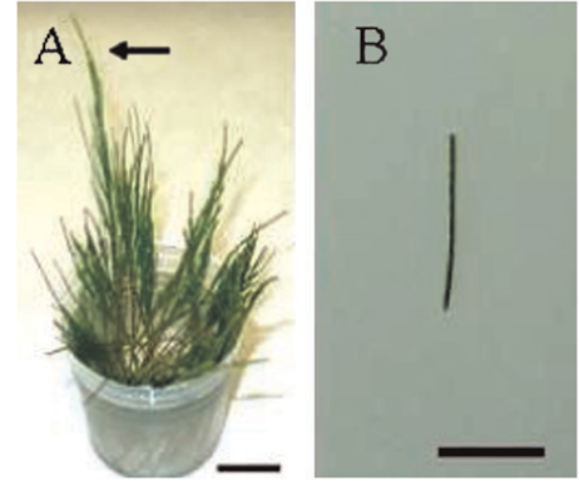

Fig. 1. Plant materials and explants. (A) Shoot tip cuttings taken from mature male trees. Bar = $1.0 \mathrm{~cm}$. (B) Shoot tip explants excised from cutting used to initiate in vitro culture. $\mathrm{Bar}=$ $1.0 \mathrm{~cm}$.

salts, $0.4 \mathrm{mg} \cdot \mathrm{L}^{-1}$ thiamine, $2.0 \mathrm{mg} \cdot \mathrm{L}^{-1}$ glycine, $100.0 \mathrm{mg} \cdot \mathrm{L}^{-1}$ myo-inositol, $0.5 \mathrm{mg} \cdot \mathrm{L}^{-1}$ pyridoxine, $0.5 \mathrm{mg} \cdot \mathrm{L}^{-1}$ nicotinic acid, $30 \mathrm{~g} \cdot \mathrm{L}^{-1}$ sucrose, supplemented with different types and concentrations of PGRs, with $20 \mathrm{~g} \cdot \mathrm{L}^{-1}$ activated charcoal (AC) (Fisher Scientific, Fair Lawn, NJ) for shoot proliferation or without any AC for rooting, respectively. The medium was adjusted to $\mathrm{pH} 5.8$ with $0.1 \mathrm{~N}$ $\mathrm{NaOH}$ before the addition of $8 \mathrm{~g} \cdot \mathrm{L}^{-1} \mathrm{TC}$ agar (PhytoTechnology Laboratories, Shawnee Mission, KS) and autoclaved at $1.2 \mathrm{~kg} \cdot \mathrm{cm}^{-2}$ for $20 \mathrm{~min}$. Cultures were kept in GA-7 vessels containing $40 \mathrm{~mL}$ of medium. Cultures were maintained at $22 \pm 3{ }^{\circ} \mathrm{C}$ with a $12 / 12$-h light/ dark photoperiod at $40 \mu \mathrm{mol} \cdot \mathrm{m}^{-2} \cdot \mathrm{s}^{-1}$ provided by cool white fluorescent lamps (Lithonia Lighting F40W/SS, Conyers GA).

Shoot proliferation: plant growth regulator effect. Four experiments (E.1 to E.4) were conducted to examine PGR types, concentrations, or combinations for shoot proliferation using entire shoot tip explants placed vertically on the medium: E.1-BA at $0,1,2$, 4,8 , or $16 \mu \mathrm{M}$; E.2-BA at $0,1,2,4,8$, and 16 $\mu \mathrm{M}$ and NAA at $0.05 \mu \mathrm{M}$; E.3 - thidiazuron (TDZ) at $0,1,2,4,8$, or $16 \mu \mathrm{M}$; and E.4-gibberellic acid $\left(\mathrm{GA}_{3}\right)$ at $0,1,2,4,8$, or $16 \mu \mathrm{M}$. PGR-free medium served as the control. We selected BA because it is a commonly used cytokinin that was effective in inducing shoot proliferation from epicotyl explants excised from in vitro-germinated seedlings of a Casuarina hybrid (Shen et al., 2009b); TDZ is also a cytokinin known to induce axillary bud proliferation in recalcitrant species (Lu, 1993); and $\mathrm{GA}_{3}$ can aid in breaking bud dormancy (Suzuki and Kitano, 2006).

A random mixture of shoot tips from the three source trees were placed vertically on media with the basal end inserted $\approx 2$ to $3 \mathrm{~mm}$ deep. There were five explants per GA-7 vessel (Magenta Corporation, Chicago, IL) and eight replicates for each treatment. During a 6-week culture period, the explant responses were recorded. If shoot proliferation occurred, the number of explants with sprouted axillary buds and the number of sprouts per explant were recorded. The per- centage of axillary bud sprouting was calculated as the number of explants with sprouted axillary buds out of the total number of explants cultured.

Only TDZ (E.3) was effective in inducing shoot proliferation. The following two experiments were conducted in an attempt to increase shoot proliferation rate using TDZ.

Explant orientation. Entire shoot tip explants were placed horizontally on the surface of medium and pressed $\approx 1 \mathrm{~mm}$ into media. Explants were cultured on MS medium supplemented with TDZ (to be comparable with the shoot proliferation experiment) at $0,1,2,4,8$, or $16 \mu \mathrm{M}$. There were five explants per GA-7 vessel and eight replicates for each treatment. Explants responses were recorded at the end of 6 weeks culture.

Explant type. We also tested detipped explants in which 1 to $2 \mathrm{~mm}$ of the shoot tip apex was removed and single-node explants formed by separating the shoot tip explants at each node. These two types of explants were cultured on MS medium supplemented with TDZ at $0,1,2,4,8$, or $16 \mu \mathrm{M}$. There were five explants per GA-7 vessel and eight replicates for each treatment. Explant responses were recorded at the end of 6 weeks culture.

In vitro rooting. The effects of IBA, IAA, and NAA on in vitro rooting were investigated. Shoots produced on MS medium supplemented with $4 \mu \mathrm{M}$ TDZ (optimal for shoot proliferation) were used for rooting experiments. Shoots were removed from GA-7 vessels and the basal ends were trimmed $\approx 2$ to $3 \mathrm{~mm}$ to remove any callus or browning tissues and then cultured on root induction media composed of MS medium supplemented with IBA, IAA, or NAA at 0 , $2.5,5,10,15$, or $20 \mu \mathrm{M}$. PGR-free medium served as the control. There were five shoots per GA-7 vessel and five replicates for each treatment. At the end of 6 weeks culture, the number of shoots forming roots, root number, and the length of the longest root of each shoot were recorded. The rooting percentage was calculated as the number of shoots forming roots out of the total number of shoots cultured.

Experimental design and statistical analysis. All experiments were established in a completely randomized design. Data were subjected to analysis of variance using SAS (SAS Institute, Inc., 1999). Mean separation was achieved by the least significant difference test at the $95 \%$ level.

\section{Results}

Shoot proliferation: plant growth regulator effects. PGR effects on shoot proliferation were only observed on MS medium supplemented with TDZ (E.3). BA, BA in combination with NAA, and $\mathrm{GA}_{3}$ at the concentrations tested did not induce any shoot proliferation. Inclusion of NAA at $0.05 \mu \mathrm{M}$ in media resulted in profuse callus formation at the base of shoot tips. Shoot proliferation occurred only when the medium was supplemented with 2 and $4 \mu \mathrm{M}$ TDZ.
TDZ at $4 \mu \mathrm{M}$ induced the greatest axillary bud sprouting $(70 \%)$ and mean number of sprouts per explant (2.3) (Table 1). The mean values at $4 \mu \mathrm{M}$ were significantly greater than at $2 \mu \mathrm{M}$ for percentage sprouting and for sprouts per explant. There was no significant difference in shoot length.

The first indication of shoot tip explant response generally occurred within 2 weeks of culture initiation. Shoot tips changed in color to a more obvious transparent green and the internode sections became swollen and barrel-shaped (Fig. 2A). Small, green lateral buds along the stem became visible within 4 weeks (Fig. 2B). Lateral buds of the more basal nodes were the first to sprout in most cultures. Lateral buds sometimes developed into a branch with many branchlets (Fig. 2C) or remained a single shoot before other lateral buds of the more apical nodes developed during the 6-week culture period (Fig. 2D). Occasionally, shoot apical meristems developed earlier than lateral buds and formed a branch with multibranchlets (Fig. 2E). Nonresponsive explants turned a dark brown color and eventually died (shoot tip necrosis).

Explant orientation. Horizontally placed entire shoot tip explants did not undergo any shoot proliferation on MS medium containing TDZ at the concentrations examined.

Explant types. There was no shoot proliferation in either the detipped or singlenode explants on MS medium containing $\mathrm{TDZ}$ at the concentrations examined.

In vitro root formation. NAA and IAA failed to induce root formation in vitro. Root formation was only observed on MS medium containing IBA depending on concentrations (Table 2). No root formation was observed on the control medium or from media with IBA at 15 and $20 \mu \mathrm{M}$. The highest rooting percentage $(68 \%)$ was obtained on MS medium supplemented with $5 \mu \mathrm{M}$ IBA. There was no significant difference in mean number of roots per explant at 2.5 and $5 \mu \mathrm{M}$ IBA, although root length differed significantly at these two concentrations. Calli usually formed first at the base of shoots within 3 weeks on root induction media. Adventitious roots were induced from calli in the next 3 weeks (Fig. 2F).

\section{Discussion}

Shoot proliferation. PGR effects on shoot proliferation of Casuarina cunninghamiana were similar to those reported by others for other species (Liu and Li, 2001; PerezTornero et al., 1999). BA has been the most popular and widely used cytokinin for stimulating shoot multiplication in a broad range of species (Gaspar et al., 1996). Seth et al. (2007) reported that BA from 0 to $11.11 \mu \mathrm{M}$ induced $38.5 \%$ to $73.86 \%$ axillary bud sprouting from mature tree shoot tip explants of Casuarina equisetifolia Forst. However, in our study, BA at concentrations ranging from 0 to $16 \mu \mathrm{M}$ failed to result in any shoot production from Casuarina cunninghamiana. TDZ at 2 and $4 \mu \mathrm{M}$ was essential to promote shoot proliferation in the present 
Table 1. Effect of thidiazuron (TDZ) on shoot proliferation of vertically placed entire shoot tip explants $(\mathrm{n}=40)$ taken from mature male trees of Casuarina cunninghamiana Miq. cultured on Murashige and Skoog medium. ${ }^{\mathrm{z}}$

\begin{tabular}{cccc}
\hline TDZ $(\mu \mathrm{M})$ & $\begin{array}{c}\text { Sprouted axillary } \\
\text { buds }(\%)^{\mathrm{y}}\end{array}$ & $\begin{array}{c}\text { Mean no. of sprouts } \\
\text { per explant }\end{array}$ & $\begin{array}{c}\text { Shoot } \\
\text { length }(\mathrm{cm})\end{array}$ \\
\hline 0 & $0 \mathrm{c}$ & $0 \mathrm{c}$ & 0 \\
1 & $0 \mathrm{c}$ & $0 \mathrm{c}$ & 0 \\
2 & $53 \mathrm{~b}$ & $1.7 \mathrm{~b}$ & $2.0 \mathrm{a}$ \\
4 & $70 \mathrm{a}$ & $2.3 \mathrm{a}$ & $1.6 \mathrm{a}$ \\
8 & $0 \mathrm{c}$ & $0 \mathrm{c}$ & 0 \\
16 & $0 \mathrm{c}$ & $0 \mathrm{c}$ & 0 \\
\hline
\end{tabular}

${ }^{\mathrm{z}}$ Data from shoot proliferation trial E.3.

${ }^{\mathrm{y}}$ Means followed by the same letter in each column are not significantly different at the $P=0.05$ level.

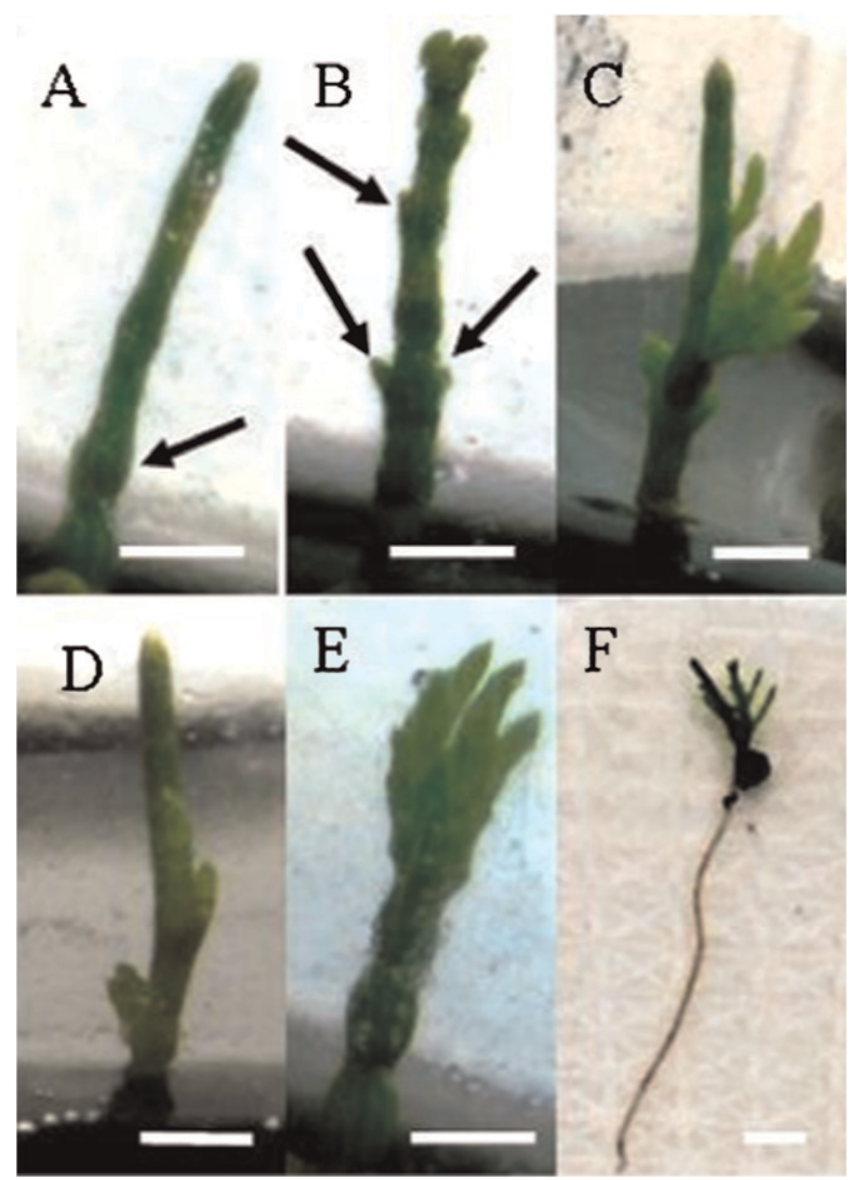

Fig. 2. Shoot proliferation and root formation of Casuarina cunninghamiana Miq. (A) Swelling of internodes after 2 weeks culture on Murashige and Skoog (MS) medium supplemented with $4 \mu \mathrm{M}$ thidiazuron. Bar $=0.5 \mathrm{~cm}$. (B) Sprouted lateral buds after 4 weeks. Bar $=0.5 \mathrm{~cm}$. (C) Lateral buds at the distant position from apical meristem developed into a branch with many branchlets. $B a r=0.5 \mathrm{~cm}$. (D) Single shoot formation from axillary buds at basal nodes. $\mathrm{Bar}=0.5 \mathrm{~cm}$. (E) Apical meristem developed into a branch with multibranchlets. Bar $=0.5 \mathrm{~cm}$. (F) Root formation from a shoot cultured on MS medium supplemented with $5 \mu \mathrm{M}$ indole-3-butyric acid for 6 weeks. Bars $=1 \mathrm{~cm}$.

Table 2. Effect of indole-3-butyric acid (IBA) on in vitro root induction from shoots derived from entire shoot tip explants taken from mature male trees of Casuarina cunninghamiana Miq. cultured on Murashige and Skoog medium.

\begin{tabular}{lccc}
\hline IBA $(\mu \mathrm{M})$ & Rooting $(\%)^{\mathrm{z}}$ & $\begin{array}{c}\text { Mean no. of roots } \\
\text { per explant }\end{array}$ & $\begin{array}{c}\text { Mean length of roots } \\
\text { per explant }(\mathrm{cm})\end{array}$ \\
\hline 0 & $0 \mathrm{c}$ & $0 \mathrm{~b}$ & $0 \mathrm{c}$ \\
2.5 & $52 \mathrm{~b}$ & $0.6 \mathrm{a}$ & $0.4 \mathrm{~b}$ \\
5 & $68 \mathrm{a}$ & $0.7 \mathrm{a}$ & $0.7 \mathrm{a}$ \\
10 & $12 \mathrm{c}$ & $0.1 \mathrm{~b}$ & $0.1 \mathrm{c}$ \\
15 & $0 \mathrm{c}$ & $0 \mathrm{~b}$ & $0 \mathrm{c}$ \\
20 & $0 \mathrm{c}$ & $0 \mathrm{~b}$ & $0 \mathrm{c}$ \\
\hline
\end{tabular}

${ }^{\mathrm{z}}$ Means followed by the same letter in each column are not significantly different at $P=0.05$ level. Data represent means of 40 explants, including eight replicates and five samples per replicate. study. Its cytokinin activity was first reported in cytokinin-dependent callus cultures of the Phaseolus lunatus cv. Kingston (Mok et al., 1982). Since then, additional evidence for a role of TDZ in promotion of axillary shoot proliferation and adventitious shoot production has been established (Briggs et al., 1988; Huetteman and Preece, 1993; Kerns and Meyer, 1986; Shen et al., 2007, 2008). The most distinguished function of TDZ has been found in propagation of woody plant species in which shoot proliferation was impossible with adenine-type cytokinins (Huetteman and Preece, 1993; Lu, 1993) as confirmed in our study. It has been reported that TDZ at low concentration (less than $1 \mu \mathrm{M}$ ) was effective in stimulating axillary proliferation, whereas higher concentrations induced callus formation or somatic embryogenesis ( $\mathrm{Lu}$, 1993; Mithila et al., 2003). In contrast, our study showed that $4 \mu \mathrm{M}$ TDZ induced the greatest $(70 \%)$ axillary bud sprouting, showing that the optimal concentration of TDZ for shoot proliferation was species and explant tissue-dependent. The mechanism of TDZ in promoting axillary bud proliferation has been shown to be through reducing dominance of the apical meristem (Thomas and Katterman, 1986). The current study supports these claims because it was noted that basal nodes responded better than terminal nodes, and more explants showed shoot proliferation from axillary buds at positions more distant from the apical bud.

In vitro rooting. Auxins are an important factor involved in rooting because they promote adventitious root formation in the vast majority of species (De Klerk, 2002). There are mainly three types of auxins used for root induction: naturally occurring IAA, synthetic NAA, and IBA. However, plants respond quite differently to these auxins in regard to adventitious root formation (De Klerk et al., 1997). Our results of in vitro rooting also confirmed this. In the current study, both IAA and NAA were ineffective in inducing adventitious root formation. Roots were only induced by IBA at concentrations at $2.5,5$, and $10 \mu \mathrm{M}$ with optimal rooting $(68 \%)$ at $5 \mu \mathrm{M}$. Parthiban et al. (1997) also found that IBA was effective in inducing adventitious root formation on shoots derived from callus cultures of C. equisetifolia, and $13.0 \mu \mathrm{M}$ was optimal, resulting in a maximum of $50 \%$ rooting. However, in a previous report, shoots derived from immature female inflorescences of $C$. equisetifolia showed $32 \%$ and $25 \%$ rooting in the presence of NAA at 0.5 and $1.0 \mu \mathrm{M}$, respectively (Duhoux et al., 1986). Differential auxin requirements among genotypes and explant sources may explain these differences.

We demonstrated that PGRs can be included among the factors affecting shoot proliferation and root induction of C. cunninghamiana. Shoot proliferation can be achieved by incorporation of TDZ in the medium and adventitious root formation by IBA. However, shoot proliferation rates and adventitious root formation ability are relatively low compared with many other 
species. Attempting to increase shoot proliferation rate with different explant types (detipped shoot tips and single node) and different explant orientations (horizontally) failed. Acclimatization of in vitro-regenerated plants to the greenhouse as well as to the field is the final step for commercial propagation. This propagation protocol must be substantially improved before such effort can be explored to examine the feasibility for large-scale propagation of this recalcitrant species.

\section{Literature Cited}

Aboel-Nil, M.M. 1987. Micropropagation of Casuarina, p. 400-410. In: Bonga, J.M. and D.J. Durzan (eds.). Cell and tissue culture in forestry. Martinus Nijhoff/Junk, Dordrecht, The Netherlands.

Briggs, B.A., S.M. McCulloch, and L.A. Edick. 1988. Micropropagation of azaleas using TDZ. Acta Hort. 226:205-208.

Castle, W.S. 2008. Field guide to identify the common Casuarina (Australian pine) species in Florida. HS 1140, Florida Cooperative Extension Service, Institute of Food and Agricultural Sciences. University of Florida, Gainesville, FL.

Castle, W.S., K.A. Langeland, and D.L. Rockwood. 2008. Casuarina cunninghamiana Miq. (River sheoak) in Florida and its potential as a windbreak plant for citrus groves. HS 1139, Florida Cooperative Extension Service, Institute of Food and Agricultural Sciences, University of Florida, Gainesville, FL.

De Klerk, G.J. 2002. Rooting of microcuttings: Theory and practice. In Vitro Cell. Dev. Biol. Plant 38:415-422.

De Klerk, G.J., T.J. Brugge, and S. Marinova. 1997. Effectiveness of indoleacetic acid, indolebutyric acid and naphthaleneacetic acid during adventitious root formation in vitro in Malus 'Jork 9'. Plant Cell Tissue Organ Cult. 49:39-44.

Duhoux, E., B. Sougoufara, and Y. Dommergues. 1986. Propagation of Casuarina equisetifolia through axillary buds of immature female in- florescences cultured in vitro. Plant Cell Rep. 3:161-164.

El-Lakany, M.H. and K.R. Shepherd. 1983. Variation in seed germinability, seedling growth, and biomass between provenances of Casuarina cumminghamiana Miq. and C. glauca Siev. For. Manag. Ecol. 6:201-216.

Gaspar, T., C. Kevers, C. Penel, H. Greppin, D.M Reid, and T.A. Thorpe. 1996. Plant hormones and plant growth regulators in plant tissue culture. In Vitro Cell. Dev. Biol. Plant. 32:272289.

Huetteman, C.A. and J.E. Preece. 1993. TDZ: A potent cytokinin for woody plant tissue culture. Plant Cell Tissue Organ Cult. 33: 105-119.

Husain, A.M.M. and P.K. Ponnuswamy. 1980. Propagation of Casuarina junghuhniana by planting shoots and root suckers. Indian For. 106:298-299.

Kerns, H.R. and M.M. Meyer. 1986. Tissue culture propagation of Acer $\times$ freemanii using TDZ to stimulate shoot tip proliferation. HortScience 21:1209-1212.

Liu, Z. and Z. Li. 2001. Micropropagation of Camptotheca acuminata Decaisne from axillary buds, shoot tips, and seed embryos in a tissue culture system. In Vitro Cell. Dev. Biol. Plant 37:84-88.

$\mathrm{Lu}, \mathrm{C.Y} .1993$. The use of TDZ in tissue culture. In Vitro Cell. Dev. Biol. Plant 29:92-96.

Lundquist, R. and J.G. Torrey. 1984. The propagation of Casuarina species from rooted stem cuttings. Bot. Gaz. 145:378-384.

Midgley, S.J., J.W. Turnbull, and R.D. Johnston (eds.). 1983. Casuarina ecology, management and utilization. CSIRO, Melbourne, Australia, pp. 286.

Mithila, J., J.C. Hall, J.M.R. Victor, and P.K. Saxena. 2003. Thidiazuron induces shoot organogenesis at low concentrations and somatic embryogenesis at high concentrations on leaf and petiole explants of African violet (Saintpaulia ionantha Wendl.). Plant Cell Rep. 21:408-414.

Mok, M.C., D.W.S. Mok, and D.J. Armstrong. 1982. Cytokinin activity of N-phenyl-N-1,2,3thidizaol-5-ylurea (TDZ). Photochem. 21:15091511.
Murashige, T. and F. Skoog. 1962. A revised medium for rapid growth and bioassay with tobacco tissue culture. Physiol. Plant. 15:473495.

Parthiban, K.T., R. Narayanan, R.S.V. Rai, C. Surendran, and V.K. Ravichandran. 1997. Callogenesis and organogenesis in Casuarina equisetifolia F. R. \& G. Forst. Indian J. For. 20:227-230

Perez-Tornero, O., L. Burgos, and J. Egea. 1999. Introduction and establishment of apricot in vitro through regeneration of shoot from meristem tips. In Vitro Cell. Dev. Biol. Plant 35:249-253.

Phelep, M., A. Petit, L. Martin, E. Duhoux, and J. Tempe. 1991. Transformation and regeneration of a nitrogen-fixing tree, Allocasuarina verticillata Lam. Bio/Tech. 9:461-466.

SAS Institute, Inc. 1999. Version 8.02. SAS Institute, Cary, $\mathrm{NC}$

Seth, R., S. Kendurkar, and R. Nadgauda. 2007. In vitro clonal propagation of Casuarina equisetifolia Forst. from mature tree-derived explants. Curr. Sci. 3:287-290.

Shen, X., W.S. Castle, and F.G. Gmitter, Jr. 2009a. Petroleum ether separation and seedcoat removal enhance seed germination of a Casuarina equisetifolia L. $\times$ C. glauca Sieb. ex Spreng hybrid. HortScience 44:1-4.

Shen, X., W.S. Castle, and F.G. Gmitter, Jr. 2009b. Micropropagation of a Casuarina hybrid (Casuarina equisetifolia L $\times$ Casuarina glauca Sieber ex Spreng) following facilitated seed germination. Plant Cell Tissue Organ Cult. 97:103-108.

Shen, X., J. Chen, and M.E. Kane. 2007. Indirect shoot organogenesis from leaves of Dieffenbachia cv. Camouflage. Plant Cell Tissue Organ Cult. 89:83-90.

Shen, X., M.E. Kane, and J. Chen. 2008. Effects of genotypes, explant sources, and plant growth regulators on indirect shoot organogenesis in Dieffenbachia cultivars. In Vitro Cell. Dev. Biol. Plant 44:282-288.

Suzuki, T. and M. Kitano. 2006. Dormancy and spring development of lateral buds in mulberry (Morus alba). Physiol. Plant. 75:188-194.

Thomas, J.C. and F.R. Katterman. 1986. Cytokinin activity induced by TDZ. Plant Physiol. 81: 681-683. 